\title{
CYBER-PR DALAM E-MUSRENBANG DI PEMERINTAH KOTA TANGERANG SELATAN
}

\author{
Amin Shabana, M.Si ${ }^{1}$ \\ Tria Patrianti, M.I.Kom ${ }^{2}$ \\ Program Studi Ilmu Komunikasi Fakultas Ilmu Sosial dan Ilmu Politik \\ Universitas Muhammadiyah Jakarta \\ Email : aminshabana78@gmail.com \\ tria.padmadisastra@gmail.com
}

\begin{abstract}
Since the launch of decentralization, the Musrenbang (Musyawarah Rencana Pembangunan) or Multi Stakeholder Consultation Forum for Development Planning is the principal instrument introduced by the Government of Indonesia for public consultation. In support of this participatory Musrenbang process, a number of regional governments including South Tangerang, have tried to increase participation by developing an online Public relations system. It is addressed to legislate transparency in budgeting and deepen the consultative approach down to the community level. The said system is electronic Musrenbang (e-Musrenbang) coordinated by Bappeda (City Development Planning Agency) together with disctrict level (Kecamatan). This research aimed to seek how the utilization of Cyber PR in Musrenbang by City Development Planning Agency of South Tangerang (Bappeda). Using qualitative data and case study method, the research conducted through in-depth interviews and FGD with bureaucrats in Bappeda, subdistrict, village, and neighbourhood. E-Musrenbang as one of the concepts of Cyber PR conducted in Bappeda Tangerang Selatan, needs to be improved. This is to foster the use the application and the involvement of stakeholders for better Tangerang Selatan in the future.
\end{abstract}

Keywords - Cyber PR, Campaign, e-Musrenbang, Bappeda

\begin{abstract}
ABSTRAK
Sejak desentralisasi diperkenalkan, instrumen utama yang diperkenalkan oleh Pemerintah Indonesia untuk konsultasi publik adalah Musrenbang (Musyawarah Rencana Pembangunan) atau Forum Konsultasi Multi Pihak untuk Perencanaan Pembangunan. Untuk mendukung proses Musrenbang partisipatif ini, sejumlah pemerintah daerah termasuk Tangerang Selatan, telah mencoba meningkatkan partisipasi dengan mengembangkan sistem PR online, untuk mengatur transparansi dalam penganggaran dan memperdalam pendekatan konsultatif hingga ke tingkat masyarakat. Sistem yang dimaksud adalah Musrenbang elektronik ( $e$-Musrenbang)
\end{abstract}


yang dikoordinasi oleh Bappeda (Badan Perencanaan Pembangunan Kota) bersama dengan tingkat kecamatan. Penelitian ini bertujuan untuk mengetahui bagaimana pemanfaatan Cyber PR dalam Musrenbang oleh Badan Perencanaan Pembangunan Kota Tangerang Selatan (Bappeda). Dengan menggunakan data kualitatif dan metode studi kasus, penelitian dilakukan melalui wawancara mendalam dan $F G D$ dengan birokrat di Bappeda, kecamatan, desa, dan lingkungan. E-Musrenbang sebagai salah satu konsep Cyber PR yang dilakukan di Bappeda Tangerang Selatan, sosialisasi pemanfaatannya perlu lebih ditingkatkan. Hal ini agar aplikasi yang dijalankan dan keterlibatan para pemangku kepentingan dapat lebih optimal bagi Tangerang Selatan yang lebih baik.

\section{Keywords - Cyber PR, Campaign, e-Musrenbang,Bappeda}

\section{PENDAHULUAN}

Perkembangan Cyber PR menunjukkan arah yang positif sejalan dengan kemajuan teknologi informasi di segala bidang. Menyadari bahwa lalu lintas informasi saat ini yang borderless, berbagai pihak tengah menyiapkan diri melakukan transformasi melalui pemanfaatan media baru dengan menggunakan internet. Kesadaran ini tidak hanya dialami dunia korporasi, tetapi juga melekat pada berbagai institusi pemerintah di tanah air. Berbagai penelitian sebelumnya telah menunjukkan peningkatan yang signifikan atas tren ini. Sayangnya, adopsi komunikasi multimedia tersebut masih belum diikuti dengan program $C y b e r P R$ yang baik.
Sebenarnya salah satu aturan yang mendorong pemanfaatan Cyber $P R$ didukung dengan terbitnya Inpres Nomor 9 Tahun 2015 tentang Pengelolaan Komunikasi Publik. Inpres ini menugaskan program dan kebijakan pemerintah secara lintas sektoral dan lintas daerah melalui berbagai saluran komunikasi kepada masyarakat secara cepat, tepat, dan mudah dimengerti. Atas dasar inpres tersebut, pemerintah pusat dan pemerintah daerah bergerak melaksanakan program e-government pada layanan publik yang dilakukan. Salah satu pemerintah kota yang telah menerapkan hal ini yaitu Pemerintah Kota Tangerang Selatan.

Wali Kota Tangerang Selatan Airin Rachmi Diany menyatakan ingin mewujudkan Tangerang Selatan 
sebagai $e$-City melalui penerapan teknologi informasi di berbagai sektor. Salah satu upaya yang telah dilakukan yaitu melalui kegiatan Musyawarah Rencana Pembangunan (Musrenbang) wilayah Kota Tangerang Selatan. Penerapan Cyber $P R$ pada Musrenbang ini menjadi tanggung jawab Badan Perencanaan Pembangunan Daerah (Bappeda) Tangerang Selatan. Bappeda telah menerapkan $e$-Musrenbang di wilayah administratif Pemerintah Kota Tangerang Selatan sejak awal 2015 lalu.

(https://www.tangerangselatankota.g o.id/main/news/view/61)

Penerapan $e$-Musrenbang diharapkan memudahkan semua warga Tangerang Selatan mengetahui program apa yang menjadi prioritas dan yang sedang dikerjakan oleh pemerintah kotanya. Data atau dokumen usulan rencana kegiatan pembangunan di masing-masing kelurahan di-input secara online. Aspirasi warga yang datang mulai dari tingkat kelurahan bisa mendorong terwujudnya Good Corporate Governance Kota Tangerang Selatan. Hal ini menjadi tugas berat dari Bappeda Tangerang Selatan untuk menyosialisasikan $e$ Musrenbang kepada tujuh kecamatan yang berada di wilayahnya. Meski wali kota menyatakan bahwa penerapan Cyber $P R$ untuk mendorong transparansi dan akuntabilitas, tetapi hal mendasar lainnya dari $e$-Musrenbang ditujukan sebagai sarana layanan informasi publik di wilayah Tangerang Selatan. (https://www.kabar6.com/tangerang/ selatan/21494-bpti-tangsel-siapkembangkan-sistem-aplikasi-sirup

Hal ini juga sesuai dengan UU Nomor 14 Tahun 2008 tentang Keterbukaan Informasi Publik. Sesuai yang diamanatkan UU ini, maka akses informasi yang sifatnya bukan rahasia negara bukan hanya harus disosialisasikan kepada masyarakat tetapi juga bisa diakses. Program $e$ Musrenbang yang diterapkan oleh pemerintah kota, termasuk Kota Tangerang Selatan, tidak dapat berjalan optimal bila tidak disertai dengan program $C y b e r P R$ yang tepat. Masih rendahnya pemerataan pemanfaatan teknologi informasi menjadi pekerjaan rumah besar bagi pemerintah tingkatan kota, termasuk 
Tangerang Selatan. Atas dasar pertimbangan tersebut, penelitian ini menjadi sangat penting sebagai pembelajaran atas pelaksanaan Cyber PR dalam menyosialisasikan $e$ Musrenbang.

Berdasarkan latar belakang penelitian yang telah dipaparkan, maka perumusan masalah dalam penelitian ini adalah Bagaimana bentuk pemanfaatan Cyber $P R$ dalam sosialisasi Musrenbang yang dilakukan oleh Badan Perencanaan dan Pembangunan Daerah Pemerintah Kota Tangerang Selatan. Perumusan masalah dalam penelitian ini akan dijawab melalui pendekatan studi kasus yang terjadi di Bappeda Tangerang Selatan. Konsep penelitian ini bersifat konstruktivisme karena hasil penelitian di obyek ini bisa memberikan pengalaman, preferensi yang berbeda pada tahapan konstruksi bagi setiap peneliti. Dugaan yang ingin dibuktikan dari penelitian ini terkait sejauh mana bentuk pemanfaatan Cyber $P R$ yang telah dilakukan Pemerintah Kota Tangerang Selatan. Definisi yang ada dalam perumusan masalah penelitian ini terkait Cyber $P R$ dan humas pemerintah daerah yang diwakili oleh Badan Perencanaan dan Pembangunan Daerah. Cyber Public Relations (Cyber-PR) adalah kegiatan kehumasan yang dilakukan dengan sarana media elektronik internet dalam membangun hubungan dua arah dan memelihara kepercayaan, pemahaman serta citra organisasi kepada publik atau khalayak. Yang menjadi batasan penelitian ini yaitu implementasi Cyber PR di Bappeda Tangerang Selatan selama tahun 2016.

Secara ringkas tujuan dari penelitian ini yaitu ingin mengetahui Bagaimana Cyber $P R$ dalam Sosialisasi $e$-Musrenbang yang dilakukan oleh Bappeda Kota Tangerang Selatan.

\section{Manfaat Penelitian}

Secara Teoritis: Hasil penelitian ini dapat memberikan kontribusi bagi pengembangan ilmu komunikasi khususnya berkaitan dengan konsep Public Relations Government dan Cyber Public Relations.

Secara Praktis: Hasil penelitian ini dapat diaplikasikan untuk menjalankan sosialisasi program dan kebijakan pemerintah yang sejenis. 


\section{KAJIAN PUSTAKA}

\section{Cyber Public Relations}

Beberapa wacana mendefinsikan pemahaman tentang Cyber $P R$.

Samsup dan Kim menyatakan bahwa Cyber $P R$ merupakan suatu relasi antara dunia maya dan pengalaman berkomunikasi secara online. Bisa disimpulkan dengan kata lain adalah komunikasi yang efektif dalam ranah maya. Sementara menurut Onggo (2004), ada enam potensi yang dapat dimanfaatkan melalui aktivitas Cyber-PR sebagai berikut:

\section{1) Komunikasi Konstan} Internet adalah media yang tak pernah terlelap setiap harinya. Melalui internet, $P R$ dapat menjangkau pulbiknya hingga ke seluruh dunia. Internet dapat menembus ruang dan waktu. Hal ini tidak dapat dilakukan oleh media lain.

\section{2) Respon yang Cepat}

Internet memungkinkan para pelaku Cyber $P R$ untuk mendapatkan respon yang cepat terhadap semua permasalahan serta pertanyaan prospek maupun pelanggan.

3) Pasar Global Internet telah menjembatani jurang pemisah secara geografis, melalui hubungan yang terjalin di dunia maya. Internet memudahkan aktivitas kehumasan untuk berkomunikasi dengan pasar global yang ada di seluruh dunia dengan biaya yang cukup murah.

4) Interaktif Internet merupakan media yang sangat interaktif. Feedback dengan mudah dapat diterima melalui media sosial yang digunakan oleh PR sehingga pengetahuan dan pemahaman publik akan segera diketahui.

\section{5) Komunikasi Dua Arah}

Komunikasi dua arah terjalin antara organisasi atau instantsi dengan publiknya. Melalui Cyber PR, organisasi dapat membangun hubungan yang kuat dan bermanfaat, yang tidak dapat dilakukan melalui media offline. 
6) Hemat Melalui Cyber PR, lembaga atau organisasi dapat menghemat biaya karena tidak membutuhkan lagi biaya cetak yang terhitung mahal.

Gita Aprinta E.B (2014) mengungkapkan sejalan dengan perkembangan teknologi, maka kegiatan komunikasi public relations dirasa tidak cukup jika hanya mengandalkan media massa tradisional. Animo masyarakat terhadap aktivitas digital bisa dibilang cukup tinggi, terutama dalam mengakses informasi.

\section{Keterbukaan Informasi Publik}

Keterbukaan informasi memberi peluang bagi rakyat untuk berpartisipasi dalam berbagai kebijakan publik. Kondisi ini sekaligus dapat mendorong terciptanya clean and good governance karena pemerintah dan badan-badan publik dituntut untuk menyediakan informasi yang lengkap mengenai apa yang dikerjakannya secara terbuka, transparan dan akuntabel. Menurut Lay (2006:9) bahwa berbagai studi pembangunan politik di negara-negara yang sudah menikmati stabilitas politik dan harmoni sosial menunjukkan bahwa kebebasan informasi dan hak rakyat untukmendapatkan informasi memainkan peranan sentral dalam keseluruhan proses politik. Tidak ada satu pun negara yang mampu menjamin stabilitas politik dan tertib sosial secara berkesinambungan, kecuali sistem tersebut difasilitasi dengan jaminan kebebasan informasi Dalam kaitannya dengan Humas pemerintah, konsep keterbukaan informasi publik (KIP) yang menjadi amanah Undang-Undang no 14 tahun 2008 merupakan petunjuk yang memberikan arah dan tujuan setiap lembaga pemerintah dalam menjalankan aktivitas kehumasannya. Aktivitas mengkomunikasikan program dan kebijakan pembangunan merupakan salah satu fungsi humas pemerintah yang strategis untuk menyebarkan data dan informasi bagi pengetahuan, pemahaman serta penerimaan publik. Penyebaran data dan informasi dapat dilakukan secara langsung maupun melalui media massa. Disinilah UU KIP menjadi koridor bagi setiap 
aktivitas kehumasan pemerintah agar program dan kebijakan dapat diterima dan dipahami dengan baik oleh publik serta mendorong adanya partisipasi seluruh stakeholder.

\section{Konsep Good Governance}

Good dalam good governance mengandung dua pengertian yaitu: Pertama, nilai yang menjunjung tinggi keinginan atau kehendak rakyat dan nilai yang dapat meningkatkan kemampuan rakyat dalam pencapaian tujuan (nasional), kemandirian, pembangunan berkelanjutan dan keadilan sosial. Kedua, aspek fungsional dari pemerintahan yang efektif dan efisien dalam pelaksanaan tugasnya untuk mencapai tujuan tersebut (Sedarmayanti, 2003:6). Sarundajang (2005:152) menjelaskan bahwa tata pemerintahan yang baik atau good governance dewasa ini sedang menjadi acuan dalam mencari perbaikan organisasi sesuai dengan tuntutan reformasi. Tata pemerintahan yang baik merupakan sebuah konsep yang akhir-akhir ini dipergunakan secara teratur dalam ilmu politik, terutama ilmu pemerintahan dan administrasi publik. Konsep itu lahir sejalan dengan konsep-konsep dan terminologi demokrasi, masyarakat madani (civil society), partisipasi rakyat, hak asasi manusia dan pembangunan masyarakat secara berkelanjutan. Sarundajang pula merumuskan bahwa istilah governance menunjukkan suatu proses di mana rakyat bisa mengatur ekonominya, institusi dan sumbersumber sosial dan politiknya tidak hanya dipergunakan untuk pembangunan, tetapi juga untuk menciptakan kohesi, integrasi, dan untuk kesejahteraan rakyatnya. PP No. 101 Tahun 2000 menjelaskan prinsip-prinsip kepemerintahan yang baik, meliputi:

1.

Profesionalitas, meningkatkan kemampuan dan moral penyelenggara pemerintahan agar mampu memberi pelayanan yang mudah, cepat, tepat dengan biaya yang terjangkau.

2. Akuntabilitas, meningkatkan akuntabilitas para pengambil keputusan dalam segala bidang yang menyangkut kepentingan masyarakat. 
3. Transparansi, menciptakan kepercayaan timbal balik antara pemerintah dan masyarakat melalui penyediaan informasi dan menjamin kemudahan di dalam memperoleh informasi yang akurat dan memadai.

4. Pelayanan prima, penyelenggaraan pelayanan publik yang mencakup prosedur yang baik, kejelasan tarif, kepastian waktu, kemudahan akses, kelengkapan sarana dan prasarana serta pelayanan yang ramah dan disiplin.

\section{5. .Demokrasi dan Partisipasi,} mendorong setiap warga untuk mempergunakan hak dalam menyampaikan pendapat dalam proses pengambilan keputusan, yang menyangkut kepentingan masyarakat baik secara langsung maupun tidak langsung

\section{Efisiensi dan Efektifitas, menjamin terselenggaranya pelayanan kepada masyarakat dengan menggunakan sumber daya yang tersedia secara optimal dan bertanggung jawab.}

7. Supremasi hukum dan dapat diterima oleh seluruh masyarakat, mewujudkan adanya penegakkan hukum yang adil bagi semua pihak tanpa pengecualian, menjunjung tinggi HAM dan memperhatikan nilainilai yang hidup dalam masyarakat. Menghubungkan tata pemerintahan yang baik (good governance) dengan keterbukaan informasi publik buka merupakan suatu keniscayaan, karena salah satu wujud dari good governance adalah adanya transparansi guna menciptakan rasa saling percaya antara pemerintah dan masyarakat.

\section{Humas Pemerintah}

Eksistensi Humas dalam suatu lembaga/instansi pemerintah merupakan keharusan secara fungsional dan operasional. Kelengkapan ini dianggap sangat penting karena falsafah negara dari rakyat, oleh rakyat dan untuk rakyat seperti yang dikehendaki dalam bentuk negara yang menganut sistem demokrasi. Sebagai negara demokrasi Humas berfungsi melayani 
rakyat, karena rakyat turut mengawasi setiap kegiatan pemerintah, apabila tidak sesuai dengan aspirasi rakyat, rakyat secara cepat akan mengeritiknya. Disinilah Humas berfungsi untuk mengelola informasi dan opini publik. Informasi mengenai kebijaksanaan pemerintah disebarluaskan, opini ublik dikaji dan diteliti seefektif mungkin untuk keperluan pengambilan keputusan dan penentuan kebijakan selanjutnya. Humas pemerintah menurut Sam Black (Effendy, 1999:37) diklasifikasikan menjadi Humas pemerintah Pusat dan Humas Pemerintah Daerah. Keduaduanya menurutnya mempunyai tugas yang sama, walaupun ruang lingkupnya berbeda. Tugas Humas pemerintah disini; pertama menyebarkan informasi secara teratur mengenai kebijaksanaan perencanaan dan hasil yang telah dicapai, kedua menerangkan dan mendidik mengenai perundang-undangan, peraturan-peraturan dan hal-hal yang berhubungan dengan kehidupan rakyat sendiri.

Melalui humasnya pemerintah dapat menyampaikan informasi atau menjelaskan hal-hal

yang berhubungan dengan kebijaksanaan dan tindakantindakan tertentu serta aktivitas

dalam melaksanakan tugas-tugas dan kewajiban kepemerintahannya.

Terdapat beberapa hal untuk melaksanakan tugas utama Humas Pemerintah:

1. Mengamati dan mempelajari tentang hasrat, keinginankeinginan dan aspirasi yang terdapat dalam masyarakat (learning about public desires and aspiration)

2. Kegiatan memberikan nasehat atau sumbang saran untuk menanggapi atau sebaliknya dilakukan oleh instansi/lembaga pemerintah seperti dikehendaki publiknya 
(advising the public about what is should desires)

3. Kemampuan untuk mengusahakan terjadinya hubungan memuaskan yang diperoleh antara hubungan public dan aparat Pemerintahan (ensuring satifactory contact between and government official)

4. Memberikan penerangan dan informasi tentang apa yang telah diupayakan oleh suatu lembaga/instansi

Pemerintahan yang bersangkutan (informing and about what an agency is doing) (Ruslan, 1999:297)

Selanjutnya menurut Sam Black (Effendy, 1999:39) ada empat tujuan utama Humas Pemerintah Daerah yaitu yaitu:

\section{To key citizen informed of the} council's policy and its dayby-day activities,

(Memelihara penduduk agar tahu jelas mengenai kebijaksanaan lembaga beserta kegiatan seharihari).
2. To give theme decisions are by the council; (Memberi kesempatan kepada mereka untuk menyatakan pandangan mengenai proyek baru yang penting sebelum lembaga mengambil keputusan).

3. To enlighten citizen them of their right and responsibilities; (Memberikan penerangan kepada penduduk mengenai cara pelaksanaan system Pemerintahan daerah dan mengenai hak-hak dan tanggungjawab mereka.

4. To promtoe a sense of civic pride (Mengembangkan rasa bangga sebagai warga Negara)

Pendapat Sam Black tersebut di atas hampir sejalan dengan pemikiran yang dikemukakan oleh Widjaya (1993:126) yang mengemukakan bahwa humas dapat ditinjau dari beberapa aspek, yakni:

1. Ditinjau dari segi kenegaraan/politik kehumasan sangat erat hubungannya dengan mekanisme demokrasi, yaitu 
pemerintah dituntut untuk menjelaskan segala sesuatu yang dikerjakan atas nama rakyat banyak (terutama dalam sistem demokrasi liberal).

2. Dalam alam demokrasi Pancasila kehumasann harus mempunyai sifat membina dan mengembangkan partisipasi rakyat serta mendidik masyarakat yang berhubungan dengan kepentingan dikalangan pemerintah dan masyarakat bersama-sama mencapai tujuan Negara.

3. Dalam negara bagaimanapun bentuk Pemerintahannya, hubungan antara pemerintah dengan masyarakat sebagai warga negara harus dipelihara dengan berbagai cara (tergantung sistem politik yang ada). Dalam masa pembangunan sekarang ini, hubungan pemerintah dan masyarakat titik beratnya pada stabilitas politik dan ketertiban umum, dan membina masyarakat yang mempunyai kesadaran tinggi untuk mencapai tujuan pembangunan nasional.
4. Guna menjaga hubungan yang jujur dan harmonis programprogram dan mekanisme sekitar hubungan tersebut, tentu saja inisiatif datang dari kita (pemerintah dan pemerintah daerah)

5. Pemerintah sama sekali tidak menghendaki adanya masyarakat yang pesimis, negatif, statis dan frustasi. Dengan mekanisme kehumasan kita hidupkan inisiatif, daya pikir, dinamika dan sumbangsih/kritik yang konstruktif.

6. Tidak semua anggota masyarakat mampu berkeinginan/menyampaikan pendapat secara rasional; banyak yang emosional, karenanya perlu usaha human relations. Uraian di atas akan lebih jelas jika kita melihat beberapa definisi humas seperti yang dikemukakan oleh Cutlip Center dan Brown (1985:6) bahwa "The management function that estabilish and maintain mutually beneficial relationship between and organization and the public on home it success of failure 
depend" Dari catatan itu, Humas dapat dilihat sebagai fungsi manajemen untuk membangun dan menjaga hubungan saling menguntungkan antara organisasi dengan berbagai pihak yang menentukan keberhasilan atau kegagalan organisasi tersebut. Ruslan (1999:34) mengemukakan bahwa fungsi pokok Humas pemerintah Indonesia pada dasarnya mengamankan kebijakan pemerintah; memberikan pelayanan, menyebarluaskan pesan atau informasi mengenai kebijakan hingga programprogram kerja nasional kepada masyarakat, menjadi komunikator dan sekaligus sebagai mediator yang proaktif dalam menyembatani kepentingan instansi pemerintah disatu pihak, dan menampung aspirasi serta memperhatikan keinginan-keinginan publiknya dilain pihak, dan berperan serta menciptakan iklim kondusif dan pembangunan nasional baik jangka pendek maupun jangka panjang. Melalui Humas,
Pemerintah dapat menjelaskan program dan kebijakannya kepada publik sehingga muncul pemahaman dan partisipasi publik tentang program dan kebijakan tersebut. Selain itu Humas berkewajiban untuk turut serta memantapkan program pemerintah dalam suatu sistem politik yang ada sekarang, agar sistem politik itu semakin baik dan mendukung pelaksanaan pemerintahan itu sendiri baik di tingkat pusat, provinsi, kota maupun kabupaten.

\section{Musrenbang}

Musrenbang dilaksanakan dalam rangka melaksanakan amanat Undang-undang Nomor 25 Tahun 2004, tentang Sistem Perencanaan Pembangunan Nasional serta Surat Menteri Negara Perencanaan Pembangunan/Kepala Bappenas Nomor 2400/M.PPN/05/2003, Tanggal 26 Mei 2003 Tentang Pedoman Penyelenggaraan Musyawarah Perencanaan Pembangunan Daerah (Musrenbangda Tahun 2004). Peraturan tersebut 
mengamanatkan

bahwa

perencanaan

pembangunan

daerah dilakukan berdasarkan

peran dan kewenangan masing-

masing guna mewujudkan

integrasi, sinkronisasi dan

sinergitas pembangunan, antar

(stakeholders)

pemangku

kepentingan. Dalam kegiatan

Musrenbang Pemerintah Kota,

pemerintah wajib menampung

aspirasi usulan program dari

masyarakat sekitar hingga tingkat

kecamatan. Berbagai usulan

tersebut bisa berupa bidang

kegiatan peningkatan pelayanan

infrastruktur, kesehatan,

pendidikan, keamanan

lingkungan, penanggulangan

masalah sosial dan program

kegiatan lainnya yang ada di

Satuan Kerja Perangkat Daerah

(SKPD) serta anggaran hibah.

Agar

penyelenggaraan

Musrenbang

Kabupaten,

Kecamatan, Kelurahan dan Desa

dapat memenuhi asas demokrasi,

\section{METODE PENELITIAN}

Pendekatan penelitian ini adalah studi kasus. Creswell mengemukakan beberapa karakteristik dari suatu studi kasus yaitu : (1) mengidentifikasi "kasus" untuk suatu studi; (2) Kasus tersebut merupakan sebuah "sistem yang terikat" oleh waktu dan tempat; (3) Studi kasus menggunakan berbagai sumber informasi dalam pengumpulan datanya untuk memberikan gambaran secara terinci dan mendalam tentang respons dari suatu peristiwa dan (4) Menggunakan pendekatan studi kasus, peneliti akan "menghabiskan waktu" dalam menggambarkan konteks atau setting untuk suatu kasus. Hal ini mengisyaratkan bahwa suatu kasus dapat dikaji menjadi sebuah objek studi (Stake, 1995) maupun mempertimbangkannya menjadi sebuah metodologi (Merriam, 1988). Peneliti bertujuan memberikan pandangan yang lengkap dan mendalam mengenai bagaimana suatu aktivitas kehumasan pemerintah dijalankan oleh Bappeda Tangsel dalam mensosialisasikan Musrenbang melalui Cyber PR. Penelitian 
studi kasus diharapkan dapat menelaah sebanyak mungkin data mengenai subjek yang diteliti. mempelajari semaksimal mungkin seorang individu, suatu kelompok, atau suatu kejadian. Penelitian studi kasus ini menjadi penting karena Pemerintah Kota Tangerang Selatan sendiri baru menjalankan $e$-Musrenbang sekitar akhir 2015 lalu. Komitmen yang dimiliki Pemerintah Kota agar memiliki system yang terintegrasi hingga tingkat RT perlu dievaluasi setelah 2 tahun dicanangkan. Situasi ini memberikan peluang yang besar bagi peneliti untuk melakukan penelitian secara mendalam, detail, intensif, dan menyeluruh terhadap aktivitas Cyber PR yang dilakukan oleh Bappeda Kota Tangsel dalam menjalankan sosialisasi program dan kebijakan terkait Musrenbang

\section{HASIL PENELITIAN}

Pembahasan penelitian ini mengacu pada apa yang disampaikan oleh Onggo (2004) yang menyatakan bahwa ada enam potensi melalui aktivitas Cyber-PR terkait sosialisasi Musrenbang di Pemkot Tangsel. Adapun data yang diperoleh adalah sebagai berikut:

\section{Komunikasi Konstan. Perihal} pewujudan komunikasi konstan melalui Cyber $P R$ yang diterapkan dalam sosialisasi $e$ Musrenbang diterapkan dalam suatu sistem terintegrasi dari pemerintah kota hingga kelurahan. Sistem yang dibentuk tersebut bernama Sistem Informasi Manajemen, Perencanaan, Penganggaran dan Pelaporan (SIMRAL). Informasi ini sesuai dengan respon yang diberikan oleh KaSie Pengendalian dan Evaluasi Perencanan Bappeda Tangsel, Irma:

E- Musrenbang atau Electronic Musrenbang (Musyawarah Pembangungan) di tingkat Kota Tangeran Selatan (Tangsel), diawali pada tahun 2015 yang lalu, sejalan dengan penerapan Sistem Informasi Manajemen, Perencanaan, Penganggaran dan Pelaporan (SIMRAL) di Kota Tangerang Selatan. EMusrenbang sendiri merupakan inovasi Pemerintah Kota 
Tangerang Selatan yang dirancang untuk mendorong transparansi dan akuntabilitas setiap data usulan pembangunan. Data atau dokumen usulan rencana kegiatan pembangunan diinput secara online. Sistem EMusrenbang di Kota Tangsel dilaksanakan dan saling terintegrasi, mulai dari Musrenbang tingkat kelurahan,kecamatan, forum perangkat daerah, kemudian musrenbang tingkat kota.

\section{Respon yang Cepat}

Pelaksanaan Cyber $P R$ yang diwujudkan dalam $e$ Musrenbang baru berjalan setahun, sehingga masih mengalami berbagai kendala teknis dan sumber daya manusia yang mengendalikannya. Permasalahan tersebut perlu mendapat perhatian serius dari pemerintah kota. Namun terlepas dari hal tersebut, Pemerintah Kota Tangerang Selatan telah memperoleh dampak positif dari sistem SIMRAL yang baru dibentuk. Dampak terbesar yaitu koordinasi yang berlangsung dirasakan lebih mudah antara pemerintah kota dengan aparatur daerah hingga tingkat yang paling bawah. Ini memungkinkan respon yang cepat terhadap semua permasalahan yang dihadapi. Ini seperti yang disampaikan oleh, Kepala Seksi Kecamatan Ciputat Timur, Syarifudin dan Sekretaris Kelurahan Cirendeu, Tri Wahyudi:

Syarifudin:

Melalui rencana E-Musrenbang ini kita bisa tahu cepat apa yang menjadi usulan. Walikota dan Bapeda juga tahu. Kalau tahun sebelumnya, di tingkat kelurahan bawa dokumen usulan dibawahnya, kemudian ditingkat kecamatan bawa juga lagi dokumennya. Sekarang tidak perlu lagi. Jadi dengan Simral ini, ketika sudah diverifikasi. Oleh verifikator, sudah ada SKPD teknis yang berwenang melaksanakan usulan itu. Misalnya terkait pendidikan nanti langsung $k e$ dinas pendidikan bisa langsung melihat. Jadi akan terlihat keseluruhan rekapan usulan. Hari itu selesai Musrenbang di tingkat kelurahan, hari itu mereka sudah bisa menyedot data. Di Simral itu sudah ada program dan SKPD terkaitnya sudah bisa kita input. Jadi memang lebih cepat. Dan ini sudah terjadi.

Tri Wahyudi:

Di tingkat kelurahan jadi lebih cepat. Tapi sayangnya Simralnya belum lancar. Namun lebih cepat 
diakses dibandingkan manual, karena sistemnya langsung. Minimal operator punya dasar pengopeasian laptop. Pendidikan tidak S-1, asal paham komputer.Proses penguploadan tidak lama. Wakidi, Ketua RW: Untuk kita, Simral ini penjelasannya masih banyak $R T$. Ketika kita bicara IT masih banyak kurangnya. Memang apa yang kita hrapkan dari bawah tentang Musrenbang masih belum. Saat ini kenyataannya, kegiatan e-musrenbang belum sepenuhnya terlaksana. Pemerintah Kota Tangerang Selatan masih menggunakan sistem manual dalam sosialisasi pelaksanaan kegiatan musrenbang. Misalnya walikota masih mengedarkan undangan secara manual yang dikeluarkan oleh Bappeda terkait pelaksanaan musrenbang.

3) Pasar Global. Terkait dengan musrenbang yang pelaksanaannya di tingkat lokal, maka target capaian bukan pada pasar global. Target capaian lebih pada penguatan sistem di tiap wilayah yang lebih terintegrasi dan satu pintu. Khusus di Pemerintah Kota Tangerang Selatan, target yang ingin diwujudkan yaitu terwujudnya Good Corporate Governance. Salah satu contoh yang terjadi yaitu pada saat proses lelang pengadaan yang dibuka kepada publik. Ini seperti yang disampaikan oleh Syarifudin:

Simral sudah mengarah kepada Good Corporate Governance. Kita berharap melalui simral ini, bisa mengetahui harga plafon yang standar. Jadi tidak perlu menerka lagi. Kemudian ada urutan skala prioraitas yang jelas. Panduan teknis dari Musrenbang masih belum kita pegang. Jadi kalau kita mengusulkan itu, tahu dinas mana yang terkait nomenklaturnya. Jadi tidak perlu repot lagi, jadi tidak ada lagi usulan ditolak akrena tidak sesuai dengan SSH, kemahalan atau kemurahan. Biasanya yang ditolak itu yang murah yang jadi kendala, kalau mahal masih bisa dikoreksi

Selain itu Cyber PR mendorong pemerintah kota lebih terarah menjalankan instrument $e$ Musrenbang. Hal ini karena pelaksanaannya yang terintegrasi mengacu pada prototype dan blue print yang dibuat hingga tingkat kecamatan. Terkait dengan hal tersebut, Syaifudin juga menambahkan :

Jadi targetnya walikota sudah mulai bertahap...diseluruh kecamatan nanti maising-masing sudah ada prototype. Dikependudukan di kelurah Cempaka Putih dll. Di Tangsel sendiri ada tim pelaksanaan 
percepatan Smart City. Yang diisi dengan melibatkan konsultan. Itu SK Walikota, ketua kepala Dinas Komunikasi dan Informatika, Wakilnya kepala Bapeda, di Kominfo ada bidang Smart City, statistic dan LPSE dan Koordinator tim pelaksana Smart City itu Kabid pengelolaan teknologi informasi dan persandian. Tahun 2016 sudah ada blue print. Tahun ini sudah ada 2 kali Bimtek tingkat kelurahan. Tahun ini ada 4 angkatan.

4) Interaktif. Melalui pelaksanaan $e$-Musrenbang, target sasaran hingga tingkat RT/RW yang berada di wilayah kota Tangerang Selatan bisa dengan mudah memberikan feedback atas suatu isu. Selain dari aspek penerima manfaat, pemerintah kota juga bisa memanfaatkan $e$-Musrenbang ini untuk mengevaluasi pengetahuan dan pemahaman publik terhadap suatu kebijakan yang akan diterapkan. Meski tetap dikombinasi dengan sistem manual di tingkat RT, yaitu melalui praMusrenbang, namun interaktifitas dengan aparat desa dibawahnya dapat terdeteksi melalui Simral. Ini seperti yang disampaikan oleh: Tri
Wahyudi, Sekretaris Kelurahan

Cirendeu:

Kita juga melakukan pra Musrenbang di tingkat $R W$. Berdiskusi dengan para RT, apa saja yang akan diusulkan. Formatnya biasanya sudah diberikan. Pendidikan apa, infrastruktur. Persiapan ketingkatan bawah juga, RT dan $R W$. $R W$ mengundang $R T$ tinggi mengisi Formulir yng diberikan, program mana yang menjadi prioritas masing-masing.

Hal ini senada dengan yang diungkapkan Syarifudin, Kepala Seksi Kecamatan Ciputat Timur:

Jadi form ditingkat kelurahan itu menjadi proposal usulan dari $R T$. Usulan itu, output an outcome apa. Ditanda-tangani $R T, \quad R W$ dan diketahui Lurah. Dokumen ini menjadi pelengkap dari dokumen pendukung. Di tingkat kecamatan pada saat rekapan, usulan yang tahun kemarin ditolak akan disampaikan. Yang belum diterima tahun sebelumnya, bisa diusulkan kembali. Usulan yang tahun sebelumnya kita tampilkan dalam bentuk Power Point dan hardcopy.

Pada pra-Musrenbang, aspirasi yang diberikan berasal dari keterwakilan setiap unsur yang berada di seluruh jenjang pemerintah kota. Ini dimaksudkan agar semua aspirasi yang akan diupload sudah mewakili semua kelompok masyarakat. Ini 
seperti yang diutarakan oleh Wakidi, Ketua RW:

Delegasi di tiap tingkat Musrenbang beda-beda. Keterwakilan perempuan harus ada. Delegasi yang dipilih itu yang kompeten dan jago berdebat serta melobi untuk memperjuangkan isu prioritas. Biasanya ada pengarah dari Bapeda. Jadi biasanya ada paparan teknis dari SKPD, Camat dan Bapeda, sebelum dimasukkan ke e-Musrenbang. Dengan adanya Simral, jadi lebih efisien. Kita memfasilitasi dari seksi kepemerintahan. Dari segi penganggaran lebih efisien.

Adapun setelah masuk ke dalam SIMRAL, ada ruang lingkup atau batasan penyusunan dan implementasi Sistem Informasi $e$ Musrenbang (Musyawarah Perencanaan Pembangunan) sebagaimana tertera dalam flow chart dibawah ini

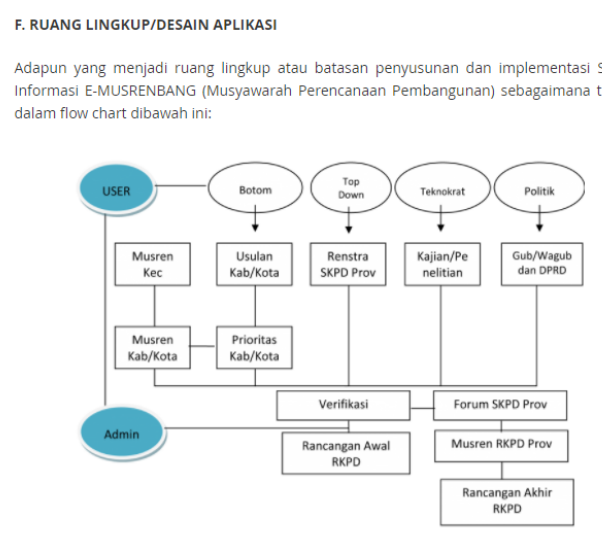

Gambar 1: Ruang Lingkung $e$ Musrenbang di Kota Tangerang Selatan

\section{5) Komunikasi Dua Arah. Sistem} yang dibangun oleh Pemerintah Kota Tangerang Selatan melalui SIMRAL sudah mulai memfasilitasi komunikasi dua arah antara pemerintah kota dengan para pemangku kepentingan yang berada di wilayah Kota Tangerang Selatan. Melalui Cyber PR ini, pemerintah kota cukup berhasil membentuk hubungan yang kuat dan bermanfaat terhadap suatu kebijakan yang akan diterapkan.

Interaktifitas yang terjadi berlangsung di beberapa tingkatan yang memang diciptakan oleh sistem yang dibuat. Terkait dengan aspek interaktif, Syaifudin menjelaskan:

Di sistem itu operator kelurahan bisa mengetahui mana yang disetujui oleh kecamatan dan dinas. Jika sudah dinput dan diverifikasi, operator sudah tahu program mana yang disetujui. Tapi memang hanya oprator saja yang tahu, verifikator dan lurah. Baru di Musrenbang tingkat kecamatan baru dibuka. Delegasi masing-masing kelompok diskusi 
akan memperjuangkan akan dimasukkan ke dalam F1 kecamatan. Jika tidak masuk kita akan dorong F2 dinas. Komunikasi Dua Arah Komunikasi dua arah terjalin antara organisasi atau instantsi dengan publiknya. Melalui cyber PR, organisasi dapat membangun hubungan yang kuat dan bermanfaat, yang tidak dapat dilakukan melalui media offline.

Komunikasi yang berlangsung dua arah ini sudah bisa terjadi hingga tingkatan yang paling bawah yaitu masyarakat. SIMRAL sangat membuka akses masyarakat untuk memberikan usulan kebutuhan wilayahnya langsung masuk ke sistem. Situasi ini seperti yang digambarkan oleh Wakidi, Ketua RW:

Sebelum adanya sosialisasi pelaksanaan e-Musrenbang, masyarakat beranggapan bahwa pelaksanaan musrenbang hanya untuk formalitas saja, dimana usulan masyarakat banyak yang tidak terealisasi. Dengan dilaksanakan sosialisasi $e$ musrenbang, memberikan gambaran bahwa masyarakat dapat mengusulkan kebutuhan wilayahnya yang diinput langsung oleh masyarakat (delegasi masyarakat) pada saat musrenbang berlangsung, kemudian secara tidak langsung masyarakat ikut serta dalam pembangunan kota. Hal tersebut yang ditanamkan Pemerintah Kota Tangerang Selatan bahwa pembangunan harus dilakukan bersama antara pihak pemerintah itu sendiri, masyarakat dan swasta. Pada akhirnya terbentuk mindset untuk berpartisipasi dalam pembangunan.

Sementara itu, alur pelaksanaan $e$ Murenbang di Pemerintah Kota Tangerang Selatan dapat tergambar sebagai berikut:

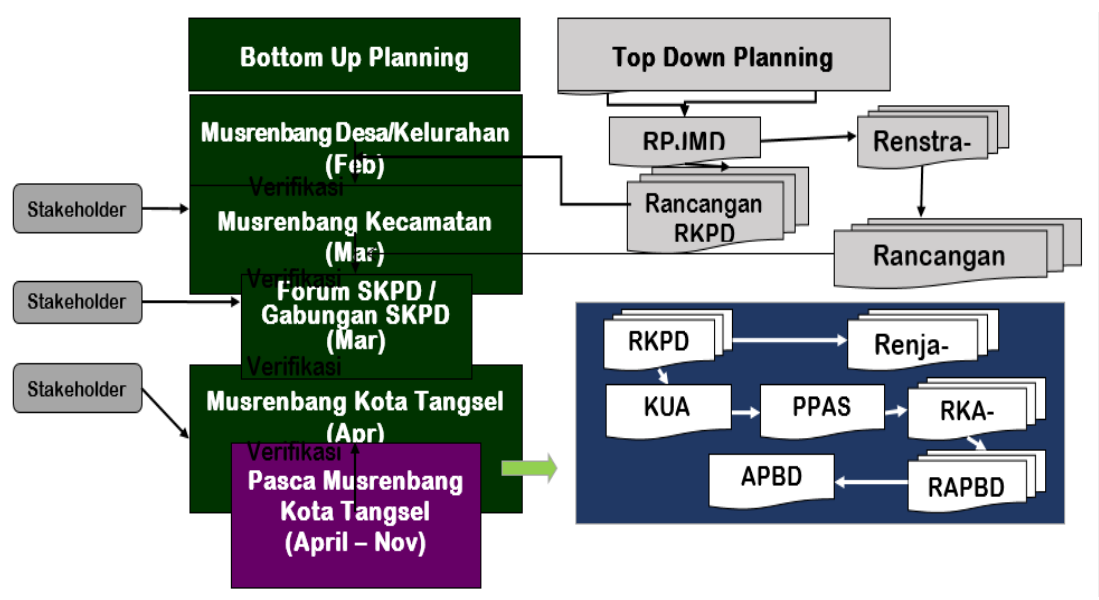

Gambar 2: Alur pelaksanaan Musrenbang di Kota Tangerang Selatan 
Dari alur Musrenbang di atas, dapat dijelaskan bahwa pada setiap pelaksanaan Musrenbang, dari Tahun 2009 sampai dengan tahun 2016 usulan tidak dibatasi baik dari jumlah usulan dan besaran pagu kewilayahannya, tetapi akan diverifikasi oleh SKPD terkait sesuai jenis usulan. Jumlah usulan setiap tahunnya akan berbeda tergantung kebutuhan masyarakat. Besaran pagu ini telah ditentukan sebelumnya dengan memperhatikan perhitungan/kriteria sebagai berikut :

a) Jumlah penduduk, luas wilayah

b) Besaran realisasi PBB dan jumlah penduduk miskin(rumah tangga sasaran)

Oleh karena itu, besaran alokasi usulan pada masing - masing kelurahan akan berbeda.

6) Hemat Melalui Cyber $P R$ yang diwujudkan dalam $e$-Musrenbang dapat memberikan dampak penghematan biaya dan efisiensi kerja kelembagaan di tingkat Pemerintah Kota hingga masyarakat. Kondisi demikian diakui oleh KaSie Pengendalian dan Evaluasi
Perencanan Bappeda Tangsel, Irma yang mengungkapkan:

Pada awal tahun anggaran pemerintah Kota Tangerang Selatan melalui BAPPEDA melaksanakan Sosialisasi eMusrenbang (termasuk penginputan dan penelusuran secara online) dengan sasaran aparatur kelurahan yang akan mengawal proses e-Musrenbang di tahapan paling awal. Sedangkan untuk mengetahui realisasi program dan kegiatan, Setiap tahun dilaksanakan monitoring, evaluasi dan pengendalian hasil pelaksanaan kegiatan sesuai perencanaan tahun sebelumnya yang dilakukan secara periodik. Hemat Melalui Cyber-PR, lembaga atau organisasi dapat menghemat biaya karena tidak membutuhkan lagi biaya cetak yang terhitung mahal.

Sementara penghematan di tingkat yang lebih bawah ditegaskan juga oleh Irma sebagai berikut:

E-Musrenbang kelurahan itu Januari, Kecamatan Februari dan Kota itu Maret. Secara berjenjang. Untuk pagu indikatif kecamatan bisa dipastikan itu Musrenbang tingkat kota. Misalnya ada usulan dengan anggaran besar,oleh kelurahan masuk F2 Kecamatan, Di kecamatan dimasukkan lagi $F$ Dinas. Verifikator harus tahu mana yang bisa disetujui. 
Biasanya yang disetujui ditingkat kelurahan itu 20 program. Nanti dari pengarah akan ditentukan brp persen di tiap kelompok bidang yang besarnya bedabeda. Masyarakat itu sering melihat Musrenbang itu untuk kebutuhan fisik dan infrastruktur. Barang yang dierikan kepada masyarakat ada aturan tersendiri, itu bentuknya hibah.
Jadi harus ada proposal tersendiri.

Berdasarkan keterangan yang diberikan Sekretaris Bappeda Tangsel, dipaparkan alur perencanaan penganggaran kota Tangsel sebagai berikut;

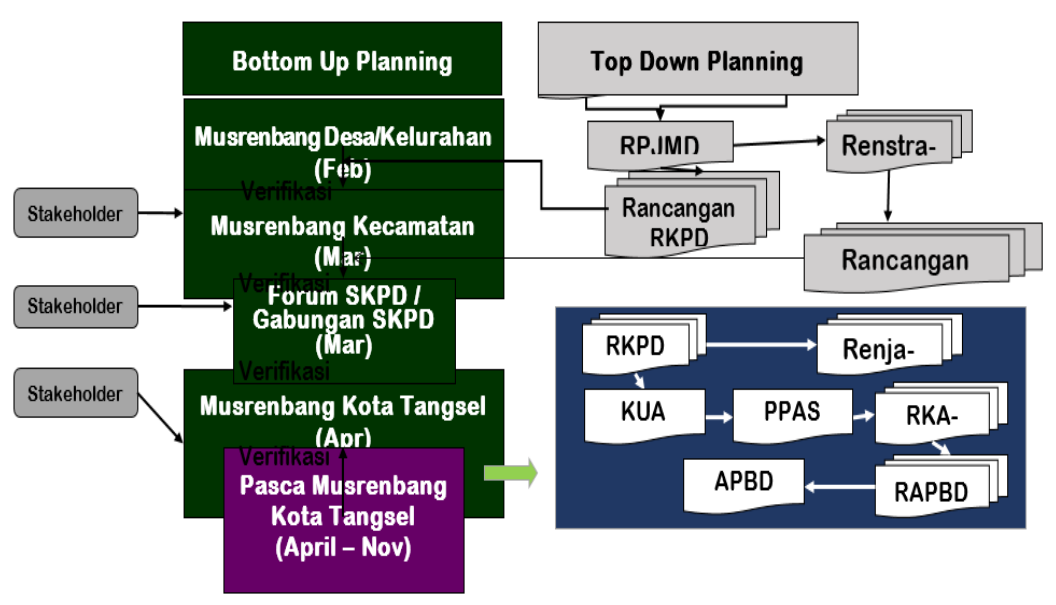

Gambar 3: Alur Musrenbang di Kota Tangerang Selatan

Secara ideal Musrenbang lebih bermakna serta berkelanjutan jika SKPD mensinkronkan kegiatan yang ada di unit kerjanya sesuai dengan

\section{SIMPULAN}

Pelaksanaan Musrenbang di Kota Tangerang Selatan telah kebutuhan masyarakat, sehingga dana yang ada di SKPD pemanfataannya lebih maksimal untuk kepentingan masyarakat. dilaksanakan melalui sistem yang ada di SIMRAL (Sistem Informasi Manjemen

Perencanaan 
Penganggaran dan Pelaporan) yang selanjutnya disebut $e$-Musrenbang. Sistem ini diawali pada tahun 2015 yang lalu. E-Musrenbang dirancang untuk mendorong transparansi dan akuntabilitas setiap data usulan pembangunan. Data atau dokumen usulan rencana kegiatan pembangunan diinput secara online. Berdasarkan aktivitas Cyber-PR yang diutarakan oleh Onggo (2004), maka pelaksanaan $e$-Musrenbang Pemerintah Kota Tangerang Selatan telah melakukan unsur-unsur yang ada dalam Cyber PR walau masih bertahap dan belum maksimal. Unsur yang dimaksud dalam Cyber $P R$ tersebut yaitu komunikasi konstan, respon yang cepat, integrasi koordinasi, interaktif, komunikasi dua arah dan penghematan.

Sarana dan Prasarana untuk menjalankan sistem $e$-Musrenbang sudah disediakan di tingkat kelurahan dan kecamatan. Namun dalam prakteknya, Sarana dan Prasarana tersebut belum berjalan maksimal karena di tingkat masyarakat, masih menggunakan sistem manual. Di tingkat kelurahan, hanya ada dua petugas yang diberikan tanggung jawab untuk mengelola sistem electronic sehingga sosialisasi atas penggunaan $e$-Musrenbang sangat bergantung pada kedua petugas tersebut.

Terkait dengan konsep Cyber-PR atau pelaksanaan fungsi kehumasan pemerintah yang berbasis online, sosialisasi yang dilakukan oleh Bappeda Tangsel merupakan komunikasi yang konstan, komunikasi dua arah yang terjalin antara organisasi atau instansi dengan publiknya, dengan respon yang cepat, interaktif, dan hemat.

Berdasarkan hasil dari penelitian dan pembahasan yang telah dikemukakan berikut ada beberapa rekomendasi pelaksanaan $e$ Musrenbang yaitu penguatan teknologi yang digunakan, peningkatan kapasitas sumber daya manusia yang menggunakan dan sosialisasi kepada semua pemangku kepentingan. mulai tingkat masyarakat, komunitas, hingga 
media massa sebagai bentuk pertanggungjawaban transparansi dan akuntabilitas yang diamanahkan oleh Undang-Undang Keterbukaan Informasi Publik.

\section{DAFTAR PUSTAKA}

\section{Buku}

Onggo, Bob Julius. 2004. Cyber Public Relations, Jakarta : Media Elex Utama.

Cutlip, Scott M., Center, Allen H., \& Broom, Glen M. 2009. Effective Public Relations: Edisi Kesembilan. Jakarta: Kencana.

Effendy,Uchjana Onong. 1999. Ilmu Komunikasi dalam Teori dan Praktek. Bandung : Rosdakarya.

Lay, Cornelis. 2006. Involusi Politik : Esei Esei Transisi Indonesia. Yogyakarta. JIPPLOD Fisipol - UGM.

Miles, M. B.\& Huberman, A.M., 1999. Analisis Data Kualitatif. Jakarta: UI Press.

Moleong, Lexy.J. 1994. Metodologi Penelitian Kualitatif. Bandung: Remadja Karya.

Ruslan, Rosady, 1999. Manajemen Humas dan Manajemen Komunikasi. Jakarta: PT Raja Grafindo Persada.
Sarundajang. 2003. Birokrasi Dalam Otonomi Daerah : Upaya Mengatasi Kegagalannya. Jakarta: Pustaka Sinar Harapan.

Sedarmayanti. 2003. Good Governance. Bandung: Mandar Maju

Widjaya, A.W, 1993. Komunikasi dan Hubungan Masyarakat. Jakarta: Bumi Aksara

Jurnal Ilmiah:

Aprinta, Gita E.B. 2014. Strategi

Cyber Public Relations dalam

Pembentukan Citra Institusi

Pendidikan Tinggi Swasta. Jurnal THE MESSENGER, Volume VI, Nomor 1, Edisi Januari.

Samsup, J. \& Yungwook, K. 2003. The Effect of Web Characteristics on Relationship Building. Journal of Public Relations Research, 15 (3).

\section{Link Internet:}

https://www.tangerangselata nkota.go.id/main/news/view $\underline{161}$

https://www.kabar6.com/tan gerang/selatan/21494-bptitangsel-siap-kembangkansistem-aplikasi-sirup

\section{Peraturan}

Undang-Undang no 14 tahun 2008

Inpres Nomor 9 Tahun 2015 tentang Pengelolaan Komunikasi Publik 